\title{
An early spring bloom of large diatoms in the ice-covered Saroma-ko Lagoon, Hokkaido, Japan-ERRATUM
}

\author{
AKIHIRO SHIOMOTO, KOJI ASAKUMA, HAN-DONG HOON, KOICHI SAKAGUCHI \\ AND KIMIHIKO MAEKAWA
}

doi: 10.1017/So025315411000361, Published by Cambridge University Press, 3 August 2011

In the above article by A. Shiomoto et al., first published online on 3 August 2011, the following errors were made. The article running heads were incorrect and should read EARLY SPRING BLOOM OF LARGE DIATOMS IN SAROMA-KO LAGOON. In Figures 3 and 5 the horizontal axis labels were incorrectly placed. In Figure $4 \mathrm{~A}$ the numbers along the horizontal axes are misaligned and in Figure 4A and B the months of February, March and April are missing. The correct Figures 3-5 are displayed below.
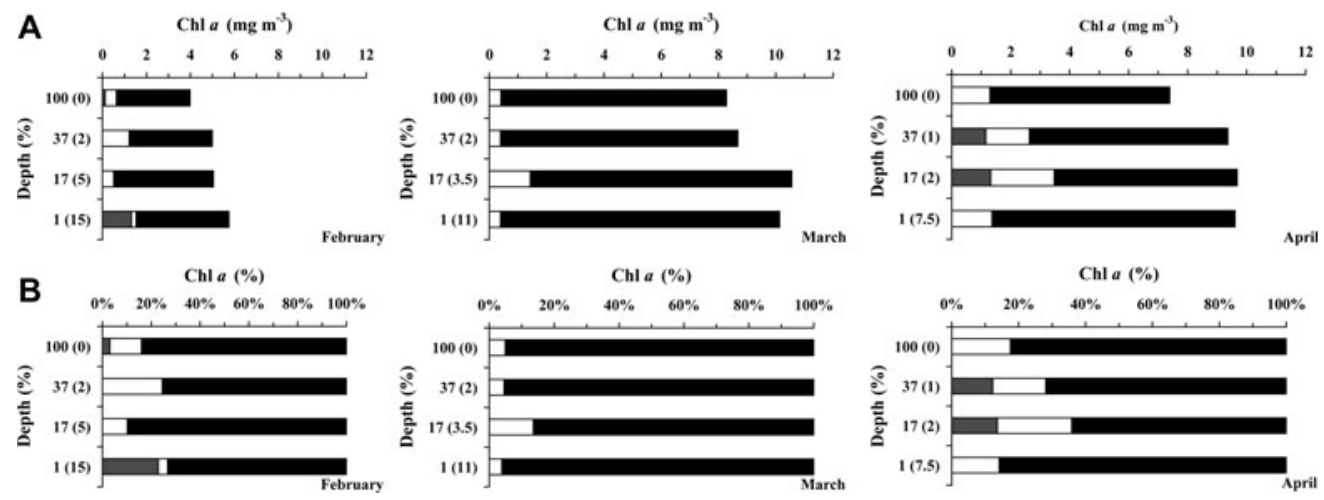

Fig. 3. Vertical profiles of size-fractionated chlorophyll- $a$ concentration (A) and chlorophyll- $a$ size composition (B) in February, March and April. $\square,<2 \mu \mathrm{m} ; \square$, $2-10 \mu \mathrm{m} ; \mathbf{\square},>10 \mu \mathrm{m}$. Figures in parentheses on the vertical axis show the depth in metres.
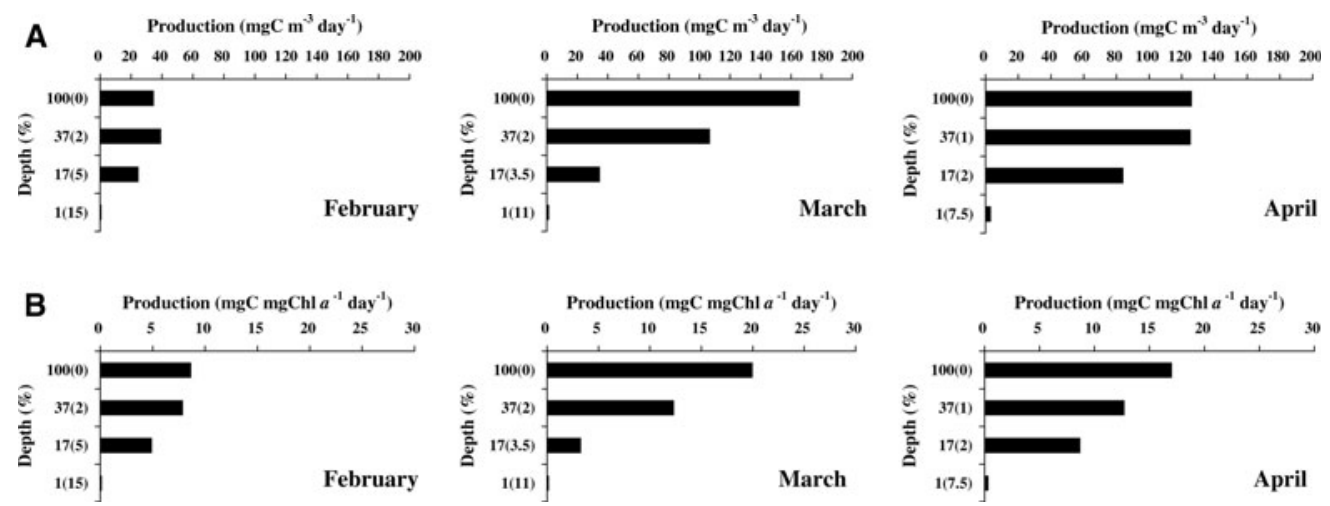

Fig. 4. Vertical profiles of primary production (A) and chlorophyll- $a$-specific primary production (B) in February, March and April. Figures in parentheses on the vertical axis show the depth in metres. 
Cell number (cells $\mathrm{r}^{\mathrm{b}}$ )

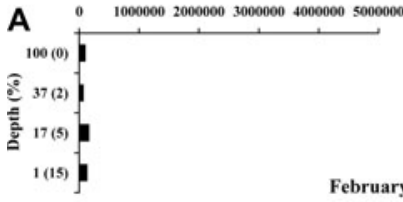

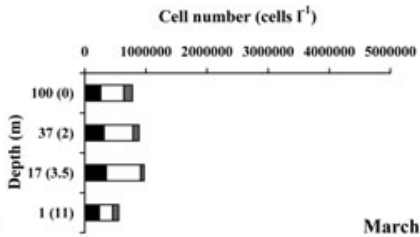
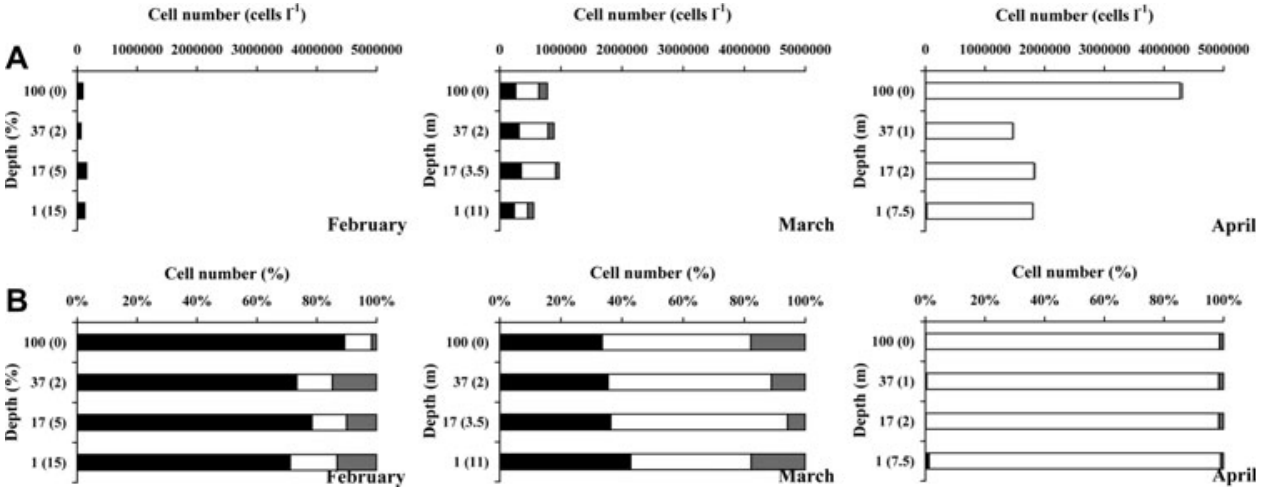

Fig. 5. Vertical profiles of cell numbers of diatom (A) and percentage contributions of Thalassiosira spp. ( $\square$ ), Chaetoceros spp. ( $\square$ ) and other diatoms ( $\square$ ) to total diatom cell numbers (B) in February, March and April. Figures in parentheses on the vertical axis show the depth in metres.

\section{REFERENCE}

Shiomoto A., Asakuma K., Hoon H.-D., Sakaguchi K. and Maekawa K. (2011) An early spring bloom of large diatoms in the ice-covered Saroma-ko Lagoon, Hokkaido, Japan. Journal of the Marine Biological Association of the United Kingdom. Published by Cambridge University Press, 3 August 2011. doi:10.1017/So025315411000361. 